\title{
Collaborative Regulation and Supply Chain Resilience: A Conceptual Paper
}

\author{
Osaro Aigbogun ${ }^{1 *}$, Zulkipli Ghazali ${ }^{2}$, and Radzuan Razali $^{3}$ \\ ${ }^{1}$ Binary University of Management and Entrepreneurship, Selangor, Malaysia \\ ${ }^{2}$ Department of Management and Humanities, Universiti Teknologi PETRONAS, Malaysia \\ ${ }^{3}$ Department of Fundamental and Applied Science, Universiti Teknologi PETRONAS, Malaysia
}

\begin{abstract}
This paper is a conceptual study that introduces the role of collaborative regulation into the supply chain resilience debate. The manufacturing supply chain of halal pharmaceuticals in Malaysia forms the context of the paper. In this paper, a critical review of previous studies on supply chain resilience, joint working relationships between supply chain actors, and collaborative involvement of regulatory authorities in supply chain relationships was carried out. Collaborative regulation for improved supply chain resilience is the coordinated, consistent, and strategic activities that includes: effective, as well as regular coordination and interactions; knowledge and information sharing, verification, and periodical monitoring, as well as enforcement of collaborative approaches to policy and regulatory control mechanisms via coercive force of isomorphism. The arguments put forward, contribute to improving knowledge, by specifying the conditions in which supply chain resilience is stronger in highly regulated contexts. This is an aspect that is ill reflected in the supply chain management literature.
\end{abstract}

Keywords: Supply chain, logistics, resilience, collaborative regulation, halal, pharmaceuticals

\section{Introduction}

Over the last 13 years, the concept of resilience has dominated the discussions in the supply chain risk management literature. Most studies have concentrated on isolating the elements/indicators of supply chain resilience. Albeit in highly regulated industries (such as the pharmaceutical industry), a more robust approach is needed, since emergency supply chain disruptions that weigh heavily on national economy/wellbeing of the population require broader solutions. Among the suggested solutions is governmental controls via regulatory functions (Matthews \& Rusinko, 2002; Gunningham, 2009; Ponomarov \& Holcomb, 2009; Papp, Papavramides, \& Perhat, 2009; Network, 2011; Preston, Lee, \& Green, 2012; Zhao, 2016).

A case in point is the Malaysian pharmaceutical industry, in which the conventional regulatory functions governing the pharmaceutical industry involves legislation/policies, control, enforcement, and monitoring. However, in the halal setting of the same industry, a collaborative supply chain relationship exists between the halal regulatory authority (JAKIM) and the companies engaged in the production of halal pharmaceuticals (Saifudin, Othman \& Elias, 2016). Research scholars (Haider, 2007; Nuruzzaman, 2009; Chowdry \& Quaddhus, 2016) view this as a supportive factor for enhancing supply chain resilience. This view is in line with the assertion of Ansell and Gash (2008) who argue that this system of collaborative regulatory governance has developed to replace adversarial and managerial approaches to policy implementation. Thus, uniting public and private stakeholders in consensus-oriented decision making. This agrees with Jaafar, et al. (2011), as well as Saifudin, et al. 2016), who assert that halal regulatory control forms collaborative interventions in supply chain relationships. This it does by aligning regulatory functions with collaborative supply chain relationships (Jaafar, et al. 2011).

${ }^{*}$ Corresponding author: osaro.aigbogun@gmail.com 
Despite the amount of studies conducted on supply chain resilience, the role of collaborative regulation has been left unexplained. Extant literature assert that halal regulation mitigates product vulnerabilities in the supply chain via the optimization of control limits (known as halal control points) along the supply chain. Here, collaboration with other supply chain stakeholders is carried out to prevent and/or mitigate vulnerabilities that might result (Jaafar et al. 2011; Tieman, 2011; Tieman, 2013, Shafii, \& Zain, 2015; Matulidia, et al. 2016; Saifudin et al. 2016). However, its contribution to mitigating process vulnerabilities, via optimization of supply chain operations is still ignored (Matulidia, et al. 2016).

\section{Rationale and Objective:}

Evidence have revealed that the halal regulatory authority (JAKIM) in Malaysia enters joint working relationships with supply chain actors, and thus facilitates the integration of operations between supply chain partners by developing a cohesive team with a shared set of goals and compatible philosophies (Melatu et al., 2011; Taliba et al., 2013; Matulidia, et al., 2016; Saifudin et al., 2016). An extensive literature review of supply chain management and logistics literature revealed limited understanding. Hence, scholars have pointed out on the need for more attention to be paid to this issue (Jaafar et al. 2011; Ibrahim \& Othman, 2014; Saifudin et al. 2016). Addressing this issue may provide supply chain managers as well as scholars in the supply chain management field with a better and more comprehensive perspective of key attributes of collaborative regulation that influence supply chain resilience. Moreover, although studies have shown the increasing dependence of contemporary supply chains on the intervention of regulatory functions, limited empirical evidence exists on the role of collaborative regulation on supply chain resilience. To bridge this gap in knowledge, the objective of this paper is to undertake a review of the role of collaborative regulation on supply chain resilience.

\section{Literature Review}

The word "regulate" has its roots in the Latin words regulare, and regula. Regulare, means 'to control', while regula means 'ruler' (Jackson, 1997). The concept of regulation embraces the action or process of regulating and the state of being regulated. Hence, regulation involves the placing of requirements by means of legal force on businesses by governments, their subsidiary bodies, or supranational authorities (OECD, 2010). However, when regulatory bodies enter into cooperative, coordinated and joint working relationship with supply chain actors for a common good; it is referred to as collaborative regulation. Zhao (2016), defines collaborative regulation as coordinated, consistent, and strategic activities involving; effective as well as regular coordination, knowledge sharing, resource sharing; exploration of synergies; and collaborative approaches to policy and regulations. Thus, in supply chain management, collaborative regulation involves the joint ability to respond to supply chain disruptions with supply chain actors through collaborative planning (Christopher \& Peck, 2004) and information- and intelligence-sharing (Jüttner \& Maklan, 2011) to coordinate the immediate response (Scholten et al. 2014; Chowdhury \& Quaddus, 2016).

Aldrich and Pfeffer (1976) argued that organizations are not able to generate all their resources internally, and therefore, they must go into transactions, and form collaborations with elements in their external environments. A major stakeholder in the external environment that has been somewhat given limited attention in the supply chain resilience literature is collaborative regulation, which is coordinated by governmental regulatory controls. In supply chain management, the impact of external environment on business organizations has been extensively studied (Chen, 2007; González-Benito et al. 2010; Yunus, 2012; Yunus \& Tadisina, 2016). The proposition that organizations form collaborative relationships with the external environment to respond to uncertainties and increasing global competition has been supported by numerous studies, such as that of Handfield and Nichols (1999), Lummus and Vokurka (1999), Mentzer et al. (2000), Ambe and Badenhorst-Weiss (2011), and Yunus (2012). According to Delloite (2012), supply chain regulation involves robust policies as well as monitoring mechanisms that guarantees adherence to proper supply chain procedures and processes. Likewise, in line with Zhao (2016), recent technological strides are placing demands on evolvement in regulatory approach. Hence, regulatory authorities worldwide are becoming more alert to the changing paradigm. For example, Jackson (1997) in his research on Academic regulation in UK 
higher education argues that regulation is a critical concept which is far more wide-ranging in scope and substance than the notion of quality assurance which it is identified with. Also, in the Oil and Gas industry, the findings of a study by Sabel, Herrigel and Kristensen (2014) points to the fact that the emergent task of collaborative regulation under uncertainties, necessitates its joint working relationship with individual organizations' systematic efforts to improve their resilience. In addition, in the telecoms industry, a report by the International Telecommunications Union (ITU), reveals that there is an overwhelming agreement by stakeholders that there is a pressing need for regulatory authorities to form collaborative relationships with industry actors especially as it concerns the present day (ITU News, 2016). As a result, organizations are required, to identify their vulnerabilities, as well as capabilities in order to ensure that the measures required to enhance resilience of supply operations are put in place accordingly (Sabel \& Zeitlin, 2008; Sabel \& Williams, 2011; Sabel, et al. 2014).

Peck (2005) in his research on the drivers of supply chain vulnerability, argues that it is when the supply chain ought to be in the established steady state that it is most vulnerable, since that is when it is most inclined to external pressures. He notes that this is when the optimization of control limits is needed, to reduce the level of vulnerabilities that results. Saifudin et al. (2016) argues that the halal regulatory authority (JAKIM) in Malaysia aptly typifies this capability by forging joint working relationship via halal control points. Authors (Bowersox, et al., 2002; Sarkis, 2003; Aruoma, 2006; Vachonb \& Klassen, 2006; Carter \& Rogers, 2008; Green Jr, Zelbst, Meacham, \& Bhadauria, 2012), assert that the aim of the emergent regulation paradigm in supply chain, is to facilitate the building and maintenance of internal behavioural features that facilitate relational exchange (Esper et al., 2010), thus protecting the integrity of the product and the process and hence the interest of the ultimate consumer. With regards to the pharmaceutical supply chain, regulation aims to protect the ultimate consumer's health, increase economic viability, harmonize and integrate well-being, and engender fair trade within and between supply chain partners (Sperber, 2005a; Aruoma, 2006; Eyinda, 2009). However, recent developments of uncertainties leading to supply chain disruptions (Starr, et al. 2003; Peck, 2005; Sheffi \& Rice, 2005; Kunreuther, 2006; Pickett, 2006; Pettit, 2008; Pettit et al. 2010,), have placed a challenge before regulatory authorities to advance methods of exerting controls in a way to proactively collaborate in managing supply disruptions across global supply chain networks (Burger \& Warner, 2012). Hence, calls have been made for innovative approaches such as collaboration between supply chain actors and regulatory authorities (Cannella \& Ciancimino, 2010; Cao \& Zhang, 201). This has led researchers (e.g, Zacharia, Nix, \& Lusch, 2011; Burger \& Warner, 2012; Fiorino \& Bhan, 2014) to propose the collaborative input of regulatory authorities. Consequently, the findings of the 2013 World Economic Forum's supply chain risk survey (World Economic Forum, 2013) has revealed that there is a need for the improvement of international and interagency compatibility of resilience standards and programmes via the collaboration of regulatory authorities with supply chain actors for optimum integration of supply chains. Also, according to Burger and Warner (2012), as well as Heckmann, Comes, and Nickel (2015), when disruptions are relatively small, supply chain members are normally well able to adjust to large disturbances, however, solutions are often ill-coordinated and incite calls for collaborative regulation as the solution of last resort. Since regulatory authorities control essential infrastructure that functions as key logistical nodes in the supply chain process flow, their collaborative involvement with supply chain actors would prevent core organizations essential to the supply chain's survival from collapsing, thus enhancing the resilience of the supply chain. In order to achieve these, it has been suggested that regulatory authorities enhance collaborative supply chain regulations across businesses and government. This can be achieved via appropriate data and information sharing, improved supply chain visibility and communication, as well as joint planning activities (Heckmann, et al., 2015; Ali et al., 2017). This calls for more involvement of the regulatory authorities as a major stakeholder in forming better collaborations with supply chain actors.

Authors; Rankin et al. (1999), Ponomarov and Holcomb (2009), Preston et al. (2012), Burger and Warner (2012), and Delloite (2012), all argued that the rising complexity of regulatory requirements and increased repercussions of noncompliance are making supply chains more dependent than ever on legal and regulatory functions. Thus, in keeping 
with such reasoning, they maintained that although some level of supply chain disruption is unavoidable, collaborative regulation helps to ensure an organization is doing everything it can to minimize its exposure to severe supply disruptions, including comprehensive business continuity plans to prevent or recover from critical disruptions. As reported in ITU (2016), the success of collaborative regulation has been recorded in Egypt's Telecoms industry in which the National Telecoms Regulatory Authority (NTRA).

The review of authors' views on regulatory functions in supply chain disruption management reveal its importance in consideration as a mediator in supply chain resilience relationships. Burger and Warner (2012) assert that lately, regulatory authorities have been increasingly challenged to understand and collaborate in the management of supply disruptions across global supply chains networks. This is in keeping with Rankin et al. (1999), Ponomarov \& Holcomb (2009), and Preston et al. (2012), who believe that national legislation via regulatory control, provides the necessary legal foundation for procurement procedures, contract enforcements, financial authority, staff accountability and other critical aspects of supply chain management. Recognizing the nature of global disruptions, means there are too many economic, security and political issues to take a one system/mono-system approach to supply chain disruption management. As noted by Preston et al. (2012), the logistics emergency teams supporting United Nation's joint logistic cluster are a practical example of companies teaming up with government and regulatory authorities to reduce supply chain disruptions, and hence improve supply chain resilience. Furthermore, Burger and Warner (2012) also note that regulatory authorities, control essential infrastructure that functions as key logistical nodes in supply systems flow and may prevent core companies essential to the supply chains survival from collapsing. This makes regulatory authorities, lead actors in supply chains. The implications of this is that the greatest capability possessed by the regulatory authority is visibility, this is because they regulate, monitor, and control all the supply chain actors and activities, hence they possess broader range of visibility compared to individual supply chain actors. If they convert this capability to collaborative regulation, then the supply chain stands a lot to gain, thus contributing to its resilience. However, despite the amount of studies conducted on supply chain resilience empirical validation of this role via statistical tests is ill reflected in the literature.

\section{METHODOLOGY}

This paper conceptually captures the role of collaborative regulation on supply chain relationship, for enhance resilience. The source of data is secondary, relying on information gathered from the literature. Extended as well as focused literature search was carried out on academic journals, scientific papers, as well as published conference proceedings using key words in line with Burns (2003). The secondary data extracted were analyzed critically to come up with the arguments advanced in the present paper.

\section{CONCLUSION}

The arguments advanced in this paper is supported by the reasonings from previous studies which have highlighted that when regulatory authorities are involved in collaborative relationships with supply chain actors, more pressure is exerted (coercive force of isomorphism) on the companies which enables them to gravitate towards resilient behaviours. For example, Frumkin and Galaskiewicz (2004), Zsidisinet, et al. (2005), Williams, et al. (2009), Yunus (2012), and Kauppi (2013) argue that when organizations are subjected to external coercive regulatory control, they tend to gravitate toward positive isomorphic transformation. This paper posit that this positive isomorphic transformation is a significant element of resilient supply chains. Also, Burger and Warner (2012), as well as Preston et al. (2012) observe that governmental regulations, control essential infrastructure that functions as key logistical nodes in systems commodity flow as a way of strengthening continuity in supply thus achieving supply chain resilience. 
Moreover, in applying the agency theory to strategies in supply chain management, the manufacturing supply chain consists of several organizations in the supply network, each assuming the role of a principal to a preceding agent, and an agent to the next principal at each node of the supply chain network. These typical multiple principal-agent relationships cause problems arising from conflicting interests between principals and agents (supply chain partners). Solving this problem requires connection of processes along the supply chain to achieve unity of efforts and goals. This is very critical in enhancing supply chain resilience. Since multiple principals and multiple agents exist in the supply chain, it is expected that the governing mechanism which acts as agent in the relationship be able to neutralize the chaos, parallel interests and information asymmetries that exist within the overall supply chain framework. This is where collaborative regulation comes into play.

Although research scholars have identified the increasing need for supply chains to be more resilient and secure, the arguments put forward in this paper suggests that during critical situations, supportive external environmental factors help nosiness organizations to continue their operations. This is in form of strategic involvements such as; joint information sharing, expertise on infrastructure development, quality certification, amongst others. To this end, future research can refine with specific modifications, the fundamental principles of collaborative regulation via the forging of joint working relationships between regulatory authorities and supply chain actors as expounded in the present paper.

\section{References}

Aldrich, H. E. \& Pfeffer, J. (1976). Environments of organizations. Annual Review of Sociology, 2, 79-105.

Ali, A., Mahfouz, A., \& Arisha, A. (2017). Analysing supply chain resilience: integrating the constructs in a concept mapping framework via a systematic literature review. Supply Chain Management: An International Journal, 22(1).

Ambe, I. M., \& Badenhorst-Weiss, J. A. (2011). Managing and controlling public sector supply chains. INTECH Open Access Publisher.

Ansell, C., \& Gash, A. (2008). Collaborative governance in theory and practice. Journal of public administration research and theory, 18(4), 543-571.

Aruoma, O. I. (2006). The impact of food regulation on the food supply chain. Toxicology, 221(1), 119-127

Bowersox, D. J., Closs, D. J., \& Cooper, M. B. (2002). Supply chain logistics management (Vol. 2). New York, NY: McGraw-Hill

Burger, K. \& Warner, J. (2012). Risk governance of food supply chains. International Risk Governance Council (IRGC), as part of project work on public sector governance of emerging risks

Cannella, S., \& Ciancimino, E. (2010). On the bullwhip avoidance phase: supply chain collaboration and order smoothing. International Journal of Production Research, 48(22), 6739-6776.

Cao, M., \& Zhang, Q. (2011). Supply chain collaboration: Impact on collaborative advantage and firm performance. Journal of Operations Management, 29(3), 163-180.

Carter, C. R., \& Rogers, D. S. (2008). A framework of sustainable supply chain management: moving toward new theory. International journal of physical distribution \& logistics management, 38(5), 360-387

Chen, H., Daugherty, P. J., \& Roath, A. S. (2009). Defining and operationalizing supply chain process integration. Journal of Business Logistics, 30(1), 63-84.

Chen, I. J., \& Paulraj, A. (2004). Towards a theory of supply chain management: the constructs and measurements. Journal of operations management, 22(2), 119-150.

Chowdhury, M.M.H. \& Quaddus, M.A. (2016). A multiple objective optimization based QFD approach for efficient resilient strategies to mitigate supply chain vulnerabilities: the case of garment industry of Bangladesh. Omega, 57(1), 5-21.

Deloitte. Supply Chain Resilience (2012): A Risk Intelligent approach to managing global supply chains. White paper,

2012 , http://www.deloitte.com/assets/DcomUnitedStates/Local\%20Assets/Documents/us_consulting_supplycha inresilience_052312.pdf (Accessed 25 Nov 2013).

Enyinda, CI, Mbah, CHN \& Ogbuehi A. (2009). An empirical analysis of risk mitigation in the pharmaceutical industry supply chain. J. Afr. Business, 10, 218-34.

Fiorino, D. J., \& Bhan, M. (2014). Supply Chain Management as Private Sector Regulation: What does it Mean for Business Strategy and Public Policy? Business Strategy and the Environment. 
Flynn, B. B., Huo, B., \& Zhao, X. (2010). The impact of supply chain integration on performance: a contingency and configuration approach. Journal of Operations Management, 28(1), 58-71.

Frumkin, P., \& Galaskiewicz, J. (2004). Institutional isomorphism and public sector organizations. Journal of public administration research and theory, 14(3), 283-307.

González-Benito, J., Reis da Rocha, D., \& Queiruga, D. (2010). The environment as a determining factor of purchasing and supply strategy: An empirical analysis of Brazilian firms. International Journal of Production Economics, 124(1), 1-10.

Green Jr, K. W., Zelbst, P. J., Meacham, J., \& Bhadauria, V. S. (2012). Green supply chain management practices: impact on performance. Supply Chain Management: An International Journal, 17(3), 290-305.

Gunningham, N. (2009). The new collaborative environmental governance: the localization of regulation. Journal of Law and Society, 36, 145-166

Haider, M.Z. (2007). Competitiveness of the Bangladesh ready-made garment industry in major international markets. Asia-Pacific Trade and Investment Review, 3(1), 3-27.

Heckmann, I., Comes, T., \& Nickel, S. (2015). A critical review on supply chain risk-Definition, measure, and modeling. Omega, 52, 119-132.

Ibrahim, S. \& Othman, M. (2014). Developing and validating halal service quality instrument for Malaysian food service establishments: A conceptual paper”, Procedia - Social and Behavioral Sciences, 130, 400 - 408

International Telecommunications Union (2016). Collaborative regulation. ITU News. 3, 9-11

Jaafar, H.S., Endut, I.R., Faisol, N., Omar, E.N. (2011). Innovation in logistics services - Halal logistics. Paper presented at the 16th International Symposium on Logistics (ISL 2011), Berlin, Germany 10-13 July.

Jackson, N. (1997). Academic regulation in UK higher education: part I - the concept of collaborative regulation. Quality Assurance in Education, 5(3), 120 - 135

Kunreuther, H., (2006). Risk and reaction: Dealing with interdependencies. Harvard International Review. 28, 3842

Lummus, R. R., \& Vokurka, R. J. (1999). Defining supply chain management: a historical perspective and practical guidelines. Industrial Management and Data Systems, 99(1), 11-17.

Manuj, I., \& Mentzer, J. T. (2008). Global supply chain risk management. Journal of business logistics, 29(1), 133155

Matthews, J. O., \& Rusinko, C. A. (2002). Regulation in the US OTC derivatives market: Towards a more collaborative framework. Journal of Derivatives \& Hedge Funds, 7(4), 337.

Matulidia, N., Jaafar, H.S., \& Bakar, A.N. (2016). The Needs of Systematic Governance for Halal Supply Chain Industry: Issues and Challenges. J. Appl. Environ. Biol. Sci., 6(11S)40-46

Melatu Samsi, S. Z, Tasnim, R., \& Ibrahim, O. (2011). Stakeholders' Role for an Efficient Traceability System in Halal Industry Supply Chain. paper presented to Annual International Conference on Enterprise Resource Planning + Supply Chain Management (ERP + SCM 2011) Penang, Malaysia, 14th - 15th March 2011, $<$ http://mmumy. academia.edu/SitiZakiahMelatuSamsi/Papers/618002/Stakeholders_Role_for_an_Efficient_Traceability_ System_in_Halal_Industry_Supply_Chain>.

Mentzer, J. T., DeWitt, W., Keebler, J. S., Min, S., Nix, N. W., Smith, C. D., \& Zacharia, Z. G. (2001). Defining supply chain management. Journal of Business logistics, 22(2), 1-25

Mentzer, J. T., Min, S., \& Zacharia, Z. G. (2000). The nature of interfirm partnering in supply chain management. Journal of Retailing, 76(4), 549-568

Narrod, C., Roy, D., Okello, J., Avendaño, B., Rich, K. \& Thorat, A. (2009). Public-private partnerships and collective action in high value fruit and vegetable supply chains. Food Policy, 34(1), 8-15.

Network, R. R. (2011). New models for addressing supply chain and transport risk. Technical report, The World Economic Forum.

Nuruzzaman, A.H. (2009). Lead time management in the garment sector of Bangladesh: an avenue for survival and growth. European Journal of Scientific Research, 33(4), 617-628.

Nuruzzaman, M. (2015). Improving competitiveness in manufacturing-wholesaling-retailing supply chains. In Quaddus, M. \& Woodside, A. (Eds), Sustaining Competitive Advantage Via Business Intelligence, Knowledge

OECD (2002). Reviews of regulatory reform: regulatory policies in OECD countries. Annex II report < https://www.oecd.org/gov/regulatory-policy/35260489.pdf>

OECD (2010). Regulatory Policy and the Road to Sustainable Growth. Organisation for Economic Co-operation and Development 2010 Report. < http://www.oecd.org/regreform/policyconference/46270065.pdf > 
Papp, E. K., Papavramides, T. C., \& Perhat, D. (2009, June). A model for a collaborative regulation of the European Air Navigation Services. In Technology Management Conference (ICE), 2009 IEEE International (pp. 18). IEEE.

Peck, H. (2005). Drivers of supply chain vulnerability: An integrated framework. International Journal of Physical Distribution \& Logistics Management, 35, 210-232

Pickett, C., (2006). Prepare for supply chain disruptions before they hit. Logistics Today, 47(6), 22-25

Ponomarov, S. Y., \& Holcomb, M. C. (2009). Understanding the concept of supply chain resilience. The International Journal of Logistics Management, 20(1), 124-143.

Preston, F., Lee, B. \& Green, G. (2012). Preparing for High-impact, Low-probability events: Lessons from Eyjafjallajökull. Chatham House, London

Rankin, J., Quick, J.D., Muziki, S., Woldeyesus, K., \& Fresle D.A. (1999). Operational principles for good pharmaceutical procurement. UNICEF and WHO

Roth, A.V., Tsay, A.A., Pullman, M.E. \& Gray, J.V. (2008). Unraveling the food supply chain: strategic insights from China and the 2007 recalls. Journal of Supply Chain Management, 44(1), 22-39.

Sabel, C., Herrigel, G., \& Kristensen, P. H. (2014). Regulation under Uncertainty: The Co-evolution of Industry and Regulation in the Norwegian Offshore Gas and Oil Industry.

Sabel, C.F., \& William, H.S. (2011). Minimalism and experimentalism in the administrative state. Geo. LJ 100, 53

Sabel, C.F., \& Zeitlin, J. (2008). Learning from difference: the new architecture of experimentalist governance in the EU. European Law Journal, 14(3), 271-327.

Saifudin, A. M., Othman, S. N., \& Elias, E. M. (2016). Construct measurement for the new model of Islamic supply chain perspective. Proceedings of UMTAS 2016

Sarkis, J. (2003). A strategic decision framework for green supply chain management. Journal of cleaner production, 11(4), 397-409

Scholten, K. \& Schilder, S. (2015). The role of collaboration in supply chain resilience, Supply Chain Management: An International Journal, 20(4), 471-484.

Scholten, K., Sharkey Scott, P. \& Fynes, B. (2014). Mitigation processes - antecedents for building supply chain resilience. Supply Chain Management: An International Journal, 19(2), 211-228.

Shafii, Z., \& Zain, S. N. (2015). Halal Assurance Mechanisms in Halal Industry: An appraisal on Its Effectiveness Towards Continuous Halal Assurance and the Way Forward. In International Conference on Education and Social sciences (pp. 1430-1438).

Shapiro, S.P. (2005). Agency theory. Annual Reviews of Sociology, 31, 263-284.

Sheff, Y. \& Rice, B. (2005). A supply chain view of the resilient enterprise”, MIT Sloan Management Review, $47(1), 41$

Sheffi, Y. (2005). The resilient enterprise. MIT Sloan Management Review, 47(1).

Sheffi, Y. (2006). Resilience reduces risk. Logistics Quarterly, 12(1), 12-14.

Sheffi, Y. (2007). Building a resilient organization. Bridge-Washington-National Academy of Engineering-, 37(1), 30

Sperber, W.H., (2005a). HACCP and transparency. Food Control, 16, 505-509

Taliba S.M., Rubin, L., \& Zhengyi, V.K. (2013). Qualitative Research on Critical Issues in Halal Logistics. Journal of Emerging Economies and Islamic Research, 1(2)

Tieman, M., Ghazali, M. C., \& Van Der Vorst, J. G. (2013). Consumer perception on halal meat logistics. British Food Journal.

Tieman, M., Jack G.A.J., Ghazali, M.C. (2012). Principles in Halal supply chain management. Journal of Islamic Marketing, 3(3), 217-243.

Tieman, M., Jack, G.A.J van, d. V., \& Maznah, C. G. (2012). Principles in halal supply chain management. Journal of Islamic Marketing, 3(3), 217-243.

Tieman, M., Maznah, C. G. (2013). Principles in halal purchasing. Journal of Islamic Marketing, 4(3), 281-293.

Vachon, S., \& Klassen, R. D. (2006). Extending green practices across the supply chain: the impact of upstream and downstream integration. International Journal of Operations \& Production Management, 26(7), $795-$ 821

Williams, J. and MacKinnon, D.P. (2008). Resampling and distribution of the product methods for testing indirect effects in complex models. Structural Equation Modeling, 15(1), 23-52.

Williams, Z., Lueg, J. E., Taylor, R. D., \& Cook, R. L. (2009). Why all the changes? An institutional theory approach to exploring the drivers of supply chain security (SCS). International Journal of Physical Distribution \& Logistics Management, 39(7), 595-618. 
Wong, C. Y., Boon-itt, S., \& Wong, C. W. Y. (2011). The contingency effects of environmental uncertainty on the relationship between supply chain integration and operational performance. Journal of Operations Management. doi: 10.1016/j.jom.2011.01.003

World Economic Forum, (2013). Global Risks 2013. World Economic Forum, Davos, Switzerland.

Yunus, E. N. (2012). Drivers of supply chain integration and the role of organizational culture: empirical evidence from Indonesia. Southern Illinois University, Carbondale.

Yunus, E. N., \& Tadisina, S. K. (2016). Drivers of supply chain integration and the role of organizational culture: Empirical evidence from Indonesia. Business Process Management Journal, 22(1), 89-115

Zacharia, Z. G., Nix, N. W., \& Lusch, R. F. (2011). Capabilities that enhance outcomes of an episodic supply chain collaboration. Journal of Operations Management, 29(6), 591-603.

Zhao, H. (2016). Why collaborative regulation is critical. International Telecommunications Union, 3, 4-21

Zhao, X., Lynch, J.G. \& Chen, Q. (2010). Reconsidering Baron and Kenny: myths and truths about mediation analysis. Journal of Consumer Research, 37(3), 197-206.

Zsidisin, G. A. (2003). A grounded definition of supply risk. Journal of Purchasing and Supply Management, 9(5), 217-224.

Zsidisin, G. A., Melnyk, S. A., \& Ragatz, G. L. (2005). An institutional theory perspective of business continuity planning for purchasing and supply management. International journal of production research, 43(16), 3401-3420. 